\title{
PENGARUH LAMA PERENDAMAN DAN KONSENTRASI NATRIUM METABISULFIT TERHADAP KANDUNGAN VITAMIN C DAN TINGKAT KECERAHAN DALAM PEMBUATAN TEPUNG UBI JALAR, TEPUNG JAGUNG DAN TEPUNG SINGKONG
}

\author{
Ika Okhtora Angelia'), Abd. Azis Hasan ${ }^{2)}$ \\ ${ }^{1,2}$ Program Studi Teknologi Hasil Pertanian, Politeknik Gorontalo \\ Email: $\underline{\text { kkaokhtora@poligon.ac.id }}^{1)}$
}

\begin{abstract}
ABSTRAK
Banyak tanaman lokal Indonesia yang berpotensi untuk diolah menjadi bahan baku pembuatan tepung. Jenis tanaman yang biasa digunakan dalam pembuatan tepung adalah umbi-umbian yang memiliki kandungan karbohidrat menyerupai gandum, diantaranya ubi jalar (putih, kuning, ungu), kentang, jagung dan singkong. Masalah yang sering dihadapi oleh bahan pangan yang mengandung karbohidrat adalah mudahnya mengalami reaksi browning karena aktifitas enzim polyphenolase dan oksidasi yang dapat merubah polyphenol menjadi diatan polykarbonil. Kerusakan yang menyebabkan perubahan warna selama penyimpanan dapat diatasi dengan penggunaan bahan tambahan yang sesuai standar dan aman untuk dikonsumsi misalnya Natrium metabisulfit. Tujuan penelitian adalah mendapatkan konsentrasi terbaik variasi lama perendaman dan konsentrasi Natrium Metabisulfit terhadap kandungan Vitamin C dan tingkat kecerahan dalam pembuatan tepung ubi jalar, tepung jagung dan tepung singkong modifikasi. Penelitian ini menggunakan rancangan faktorial dengan tiga kombinasi perlakuan dan masing-masing perlakuan diulang sebanyak tiga kali. Penelitian ini menghasilkan kesimpulan bahwa perlakuan A3N3 yakni kombinasi lama perendaman 45 menit dan konsentrasi Natrium Metabisulfit 3 g/l merupakan perlakuan terbaik dilihat dari hasil uji tingkat kecerahan dan kadar vitamin $\mathrm{C}$ pada tepung ubi jalar, jika dibandingkan berdasarkan bahan yang diuji yakni tepung singkong dan tepung jagung. Sehingga tepung ubijalar dengan perlakuan tersebut memiliki karakteristik dan kualitas yang terbaik sebagai komoditi sumber pangan lokal substitusi tepung terigu.
\end{abstract}

Kata kunci: tepung ubi jalar, tepung jagung, tepung singkong modifikasi, lama perendaman, natrium metabisulfit

\section{ABSTRACT}

The types of plants commonly used to make flour include tubers that have carbohydrates that resemble as wheat are sweet potatoes, potatoes, corn, and cassava. The problem often faced by food containing carbohydrates is easy to a browning reaction because of the activity of polyphenols and oxidation enzymes which can convert polyphenols into polycarbonate insulation. The defective that causes color changes during storage can be overcome by using additives that are standard and safe for consumption such as Natrium Metabisulfite. The effect of soaking time on Natrium Metabisulfite on the whitish degree of flour will also be studied. This study was conducted to determine Vitamin $C$ level and the whitish degree of flour in the process of making cassava flour, sweet potato flour, and corn flour. The research used factorial design with three treatment combinations, and each treatment was repeated three times with two factors, soaking length (15 minutes, 30 minutes, 45 minutes) and Natrium Metabisulfite concentration $(1 \mathrm{~g} / \mathrm{l}, 2 \mathrm{~g} / \mathrm{l}, 3 \mathrm{~g} / \mathrm{l})$. The results showed that sweet potato flour of had the highest significant effect the whitish degree of flour (treatment A3N3) and vitamin $C$ (treatment A2N3). The soaking length and Natrium Metabisulfite had a significant effect on the whitish degree of flour and vitamin $C$.

Keywords: cassava flour, sweet potato flour and corn flour, level of water, vitamin C.

\section{PENDAHULUAN}

\subsection{Latar Belakang}

Persediaan pangan dari tahun ke tahun diprediksi akan terus berkurang dengan semakin berkurangnya lahan pertanian akibat tingginya angka kelahiran, perumahan dan industrialisasi. Upaya untuk meningkatkan persediaan stok pangan tidak hanya dengan menambah kapasitas produksi melainkan dengan beberapa cara diantaranya memanfaatkan bahan-bahan pangan lokal yang belum dimanfaatkan atau dengan kata lain penggunaannya masih terbatas. Selain itu kita juga perlu mengetahui karakteristik bahan pangan tersebut sehingga kita bisa mengolahnya serta memperbaiki teknologi pengolahannya menjadi lebih modern.

Saat ini penggunaan bahan pangan seperti jagung, singkong dan ubi jalar sebagai bahan pangan masih tergolong rendah (Andoko dan Parjimo, 2008; Hidayat dkk, 2007: Prabawati dkk 2011). Padahal Indonesia memiliki aneka jenis umbi-umbian yang beraneka ragam dan 
tersebar di seluruh Indonesia. Biasanya umbi-umbian hanya dimanfaatkan sebagai bahan pembuat makanan tradisional dan diolah dengan cara digoreng, dikukus, dan dibakar.

Pra perlakuan sebelum pembuatan tepung yang umum dilakukan adalah blansing, yang bertujuan untuk menonaktifkan enzim yang terdapat pada permukaan bahan tersebut, dan juga untuk mempermudah pengeringan. Tetapi dengan blansing tersebut zat yang larut air, terutama vitamin $\mathrm{C}$ akan tercuci dan hilang kira-kira setengah dari kandungan vitamin C hilang akibat blansing dan dehidrasi, dimana jumlah kehilangan tersebut sangat tergantung dari cara blansing dan pengeringan yang dlakukan.

Menurut Asgar dan Musaddad (2008), perlakuan blansing dapat mengaktifkan asam askorbat dan dapat menstabilkan vitamin C. Perlakuan dengan media air akan lebih cepat menghilangkan asam askorbat dibandingkan dengan perlakuan dengan media uap. Hal ini dikarenakan vitamin $\mathrm{C}$ yang terdapat pada bahan ikut larut dalam air. Walaupun blansing dapat mengakibatkan kehilangan vitamin $\mathrm{C}$ beberapa peneliti telah membuktikan bahwa blansing itu sendiri dapat mencegah kehilangan vitamin $\mathrm{C}$ selama pengeringan dan penyimpanan, karena enzim yang terdapat pada permukaan bahan menjadi inaktif.

Ada dua faktor mempengaruhi kehilangan asam askorbat oleh perebusan, yaitu larutnya vitamin C dalam air rebusan dan destruksi oksidatif yang terjadi oleh katalisa enzim pada waktu periode pemanasan mula, sebelum enzim itu menjadi inaktif oleh panas tinggi. Pada pembuatan tepung cabai, penggunaan Natrium metabisulfit $0,2 \%$ menghasilkan warna cabai yang lebih baik bila dibandingkan tanpa bahan pencelup. Demikian juga kandungan vitamin C-nya juga lebih baik (Murtiningrum dkk, 2012). Natrium metabisulfit merupakan bahan pengawet yang digolongkan kedalam garam-garam sulfit dan merupakan bentuk anhidrida asam sulfit. Natrium metabisulfit biasa digunakan pada bahan pangan untuk mencegah pencoklatan enzimatis dan non-enzimatis, sebagai pemutih, anti oksidan dan penghambat pertumbuhan kapang dan khamir (Rukmana, 1997).

Cara membuat tepung dari umbi-umbian juga tergolong mudah, hanya saja diperlukan pretreatment sebelum proses pembuatan agar memperoleh hasil yang diharapkan. Bahan pangan yang mengandung karbohidat secara alami dapat mengalami reaksi browning karena aktifitas enzim polyphenolase dan oksidasi yang dapat merubah polyphenol menjadi diatan polykarbonil. Kerusakan yang menyebabkan perubahan warna selama penyimpanan dapat diatasi dengan penggunaan bahan tambahan yang sesuai dan aman dikonsumsi misalnya Natrium metabisulfit. Pengaruh lama perendaman pada Natrium metabisulfit terhadap derajat keputihan tepung juga akan dikaji. Menurut penelitian sebelumnya, penggunaan natrium metabisulfit dapat membantu keberhasilan proses pre-treatment. Begitu pula dengan perlakuan variasi lama perendaman dapat mengurangi proses pencokelatan (browning) sehingga kualitas tepung menjadi lebih baik. Saat ini pemanfaatan pati yang berasal dari umbi-umbian sebagai tepung atau produk lain masih sangat terbatas. Hal ini diakibatkan karena terbatasnya informasi mengenai sifat fitokimia dan teknologi proses pembuatannya.

\subsection{Rumusan Masalah}

Rumusan masalah pada penelitian ini adalah bagaimana menentukan pengaruh lama perendaman dan konsentrasi Natrium metabisulfit terbaik dalam pembuatan tepung ubi jalar, jagung dan tepung singkong terhadap kandungan Vitamin $\mathrm{C}$ dan tingkat kecerahan sehingga mampu menghasilkan tepung dengan karakteristik dan kualitas yang baik sebagai komoditi sumber pangan lokal substitusi tepung terigu.

\section{METODE PENELITIAN}

\subsection{Tempat dan Waktu Penelitian}

Penelitian ini telah dilaksanakan pada bulan Mei - September 2018 di Laboratorium Teknologi Hasil Pertanian Politeknik Gorontalo.

\subsection{Bahan dan Alat Penelitian}

Bahan baku yang digunakan dalam penelitian ini adalah ubi jalar, jagung dan singkong. Bahan untuk analisis antara lain aquades, larutan buffer, follin, Natrium Metabisulfit dan bahan kimia lainnya.

Alat yang digunakan dalam penelitian ini adalah kompor, panci, baskom, pisau, serta peralatan untuk analisis seperti peralatan glassware, mortar, timbangan analitik, shaker, vortex, hand refraktometer, color reader, centrifuge, dan spektrofotometer.

\subsection{Rancangan Penelitian}

Penelitian ini dilakukan dengan melakukan pre-treatment pada ubi jalar, singkong dan jagung. Pre-treatment dilakukan sebagai upaya pencegahan browning yang dapat mengurangi kualitas dan derajat keputihan pada pembuatan tepung. Rancangan yang digunakan adalah Rancangan Acak Lengkap Faktorial, sedangkan percobaan yang digunakan adalah percobaan faktorial yang terdiri dari 2 faktor yaitu lama perendaman yang dilambangkan dengan huruf A, dan konsentrasi Natrium Metabisulfit yang dilambangkan dengan huruf $\mathrm{N}$.

Faktor 1 = Lama Perendaman (A) terdiri atas tiga tingkatan yaitu :

$$
\begin{aligned}
& \text { A1 }=15 \text { menit } \\
& \text { A2 }=30 \text { menit } \\
& \text { A3 }=45 \text { menit }
\end{aligned}
$$


Faktor $2=$ Konsentrasi Natrium metabisulfit (N) terdiri atas tiga tingkatan yaitu :

$$
\begin{aligned}
& \mathrm{N} 1=1 \mathrm{~g} / \mathrm{l} \\
& \mathrm{N} 2=2 \mathrm{~g} / \mathrm{l} \\
& \mathrm{N} 3=3 \mathrm{~g} / \mathrm{l}
\end{aligned}
$$

Pada penelitian ini masing-masing perlakuan diulang 3 kali sehingga diperoleh 27 satuan percobaan. Perlakuan yang memiliki kemampuan paling tinggi dalam mencegah kerusakan antioksidan akibat reaksi pencokelatan enzimatis pada tepung ubi jalar, tepung jagung dan tepung singkong merupakan perlakuan terbaik.

\subsection{Pelaksanaan Penelitian}

Penelitian ini merupakan upaya pencegahan kerusakan antioksidan akibat reaksi pencokelatan enzimatis pada pembuatan tepung yang berasal dari ubi jalar putih, tepung jagung dan tepung singkong. Pada tahap pertama dipilih umbi yang diameternya berukuran relatif sama, dicuci bersih kemudian dipilih umbi dengan berat $\pm 250 \mathrm{~g}$, kemudian dilakukan proses perendaman. Perendaman dilakukan dengan mengkombinasikan 2 perlakuan yaitu konsentrasi Natrium Metabisulfit pada tiga level yaitu $1 \mathrm{~g} / \mathrm{l}, 2 \mathrm{~g} / \mathrm{l}$ dan $3 \mathrm{~g} / \mathrm{l}$ dan perlakuan lama perendaman pada tiga level yaitu 15 menit, 30 menit dan 45 menit. Perlakuan tersebut dilakukan dengan tiga kali ulangan. Setelah itu umbi didinginkan dan dikupas hingga $1 \mathrm{~mm}$ dari kulit, kemudian dilakukan proses pengirisan hingga tipis-tipis (pada ubi jalar dan singkong) dan pemipilan (pada jagung) dan dilakukan pengeringan dengan oven pada suhu $60^{\circ} \mathrm{C}$ selama 10 jam hingga proses penepungan selesai dan siap di uji secara kimiawi (uji kadar vitamin $\mathrm{C}$ dan tingkat kecerahan).

\subsection{Analisis Data}

Analisis data pada penelitian ini menggunakan analisis ragam (Analysis of Variant atau Annova) metode Rancangan Acak Lengkap percobaan faktorial. Apabila hasil analisis terdapat pengaruh yang signifikan, dilanjutkan dengan uji jarak berganda Duncan (DMRT). Pengolahan data menggunakan program SPSS. Penentuan perlakuan terbaik dengan menggunakan metode deskriptif.

\section{HASIL DAN PEMBAHASAN}

\subsection{Kadar Vitamin $\mathbf{C}$}

Hasil analisis ragam kadar vitamin $\mathrm{C}$ menunjukkan bahwa faktor lama perendaman, konsentrasi natrium metabisulfit, dan interaksi kedua faktor tidak memberikan pengaruh nyata $(\alpha=0,05)$ terhadap kadar vitamin $\mathrm{C}$ tepung singkong dan tepung ubi jalar, namun memberikan pengaruh yang nyata terhadap Hal ini mengindikasikan bahwa penambahan atau pengurangan lama waktu pencelupan dan konsentrasi Natrium Metabisulfit, tidak akan berpengaruh secara signifikan terhadap perubahan nilai kadar vitamin $\mathrm{C}$ tepung singkong dan tepung ubi jalar.

Hasil analisis ragam kadar vitamin $\mathrm{C}$ tepung jagung menunjukkan bahwa interaksi antara perlakuan dan lama perendaman memberikan pengaruh nyata $(\alpha=0,05)$ terhadap kadar vitamin $C$ tepung jagung. Sedangkan faktor konsentrasi Natrium Metabisulfit tidak berpengaruh nyata terhadap perubahan nilai kadar vitamin $\mathrm{C}$ pada tepung jagung. Artinya, penambahan atau pengurangan lama waktu perendaman dapat meningkatkan atau menurunkan kadar vitamin $\mathrm{C}$ dalam bahan. Akan tetapi, penambahan atau pengurangan konsentrasi Natrium Metabisulfit tidak berpengaruh signifikan terhadap peningkatan atau penurunan kadar vitamin $\mathrm{C}$ pada tepung jagung.Hasil analisa rerata kadar vitamin $\mathrm{C}$ tepung jagung dengan perlakuan lama perendaman dan konsentrasi Natrium Metabisulfit berkisar antara 2,63 mg - 5,93 mg (Tabel 1).

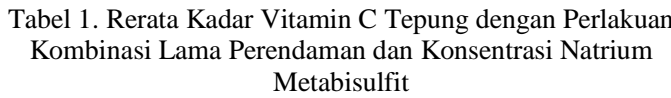

\begin{tabular}{|c|c|c|c|c|}
\hline $\begin{array}{c}\text { Lama } \\
\text { (menit } \\
\text { ) }\end{array}$ & $\begin{array}{c}\text { Natrium } \\
\text { Metabisulfi } \\
\mathbf{t} \\
(\mathrm{g} / \mathrm{L})\end{array}$ & $\begin{array}{c}\text { Tepung } \\
\text { Singkon } \\
\text { g } \\
(\mathrm{mg})\end{array}$ & $\begin{array}{l}\text { Tepun } \\
\text { g Ubi } \\
\text { Jalar } \\
\text { (mg) }\end{array}$ & $\begin{array}{c}\text { Tepung } \\
\text { Jagung } \\
\text { (mg) }\end{array}$ \\
\hline \multirow{4}{*}{15} & 1 & 3,07 & 5,05 & $5,27^{d}$ \\
\hline & 2 & 2,85 & 6,59 & $5,49^{d}$ \\
\hline & 3 & 3,07 & 6,79 & $5,93^{d}$ \\
\hline & 1 & 3,29 & 6,37 & $3,95^{\mathrm{c}}$ \\
\hline \multirow[t]{2}{*}{30} & 2 & 3,07 & 7,46 & $2,85^{\mathbf{a b}}$ \\
\hline & 3 & 3,51 & 7,24 & $2,63^{\mathrm{a}}$ \\
\hline \multirow{3}{*}{45} & 1 & 2,85 & 7,24 & $3,08^{\mathbf{a b}}$ \\
\hline & 2 & 3,73 & 7,46 & $3,52^{\mathbf{b c}}$ \\
\hline & 3 & 3,74 & 7,90 & $3,08^{\mathbf{a b}}$ \\
\hline
\end{tabular}
Metabisulfit

Keterangan: Angka rerata yang diikuti huruf yang sama pada kolom yang sama tidak berbeda nyata pada uji Duncan $5 \%$

Berdasarkan Tabel 1, kadar vitamin C tepung jagung tertinggi diperoleh pada perlakuan kombinasi lama perendaman 15 menit dan konsentrasi Natrium Metabisulfit $3 \mathrm{~g} / \mathrm{l}$ yakni sebesar 5,93 $\mathrm{mg}$. Nilai vitamin $\mathrm{C}$ terendah diperoleh pada perlakuan kombinasi lama perendaman 30 menit dan konsentrasi natrium metabisulfit $3 \mathrm{~g} / \mathrm{l}$ dengan nilai sebesar 2,63 mg.

Lama perendaman dan tingginya konsentrasi Natrium Metabisulfit dapat memperkuat jaringan pada jagung sehingga vitamin $\mathrm{C}$ yang terdapat dalam bahan tidak mudah larut dan hilang (Kumalaningsih dkk 2004).

\subsection{Tingkat Kecerahan Tepung}

Hasil analisis ragam, menunjukkan terdapat pengaruh nyata $(\alpha=0,05)$ faktor konsentrasi Natrium 
Metabisulfit dan interaksi perlakuan lama perendaman dan konsentrasi natrium metabisulfit. Hal ini menunjukkan bahwa penambahan Natrium Metabisulfit akan mempengaruhi perubahan kecerahan tepung singkong. Akan tetapi untuk faktor lama perendaman tidak berpengaruh nyata terhadap kecerahan tepung singkong. Tingkat kecerahan tepung singkong dengan perlakuan kombinasi lama perendaman dan konsentrasi natrium metabisulfit berada pada kisaran nilai 98,65 - 100,00 (Tabel 2).

Hasil analisis ragam tepung ubijalar menunjukkan bahwa faktor konsentrasi Natrium Metabisulfit dan interaksi antara perlakuan lama perendaman dan konsentrasi Natrium Metabisulfit tidak memberikan pengaruh nyata $(\alpha=0,05)$ terhadap tingkat kecerahan tepung ubijalar. Sedangkan faktor lama perendaman berpengaruh nyata terhadap tingkat kecerahan tepung. Artinya, penambahan Natrium Metabisulfit dengan konsentrasi terendah pun sudah dapat mempertahankan tingkat kecerahan tepung ubijalar.

Berbeda halnya dengan faktor lama perendaman yang memberikan pengaruh nyata, artinya semakin lama waktu perendaman maka semakin tinggi tingkat kecerahan tepung ubijalar. Tingkat kecerahan tepung ubijalar dengan perlakuan kombinasi lama perendaman dan konsentrasi natrium metabisulfit berada pada kisaran nilai 94,30 - 100,00 (Tabel 2).

Tabel 2. Rerata Tingkat Kecerahan Tepung dengan Perlakuan Kombinasi Lama Perendaman dan Konsentrasi Natrium Metabisulfit

\begin{tabular}{ccccc}
\hline $\begin{array}{c}\text { Lama } \\
\text { (menit } \\
\text { ) }\end{array}$ & $\begin{array}{c}\text { Na. } \\
\text { Metabi } \\
\text { Sulfit } \\
\text { (g/L) }\end{array}$ & $\begin{array}{c}\text { Tepun } \\
\text { gingko } \\
\text { ng }\end{array}$ & $\begin{array}{c}\text { Tepun } \\
\text { g Ubi } \\
\text { Jalar }\end{array}$ & $\begin{array}{c}\text { Tepung } \\
\text { Jagung }\end{array}$ \\
\hline \multirow{2}{*}{15} & 1 & $99,75^{\mathrm{b}}$ & $97,25^{\mathrm{ab}}$ & $87,30^{\mathrm{a}}$ \\
& 2 & $100^{\mathrm{b}}$ & $100^{\mathrm{b}}$ & $87,60^{\mathrm{ab}}$ \\
& 3 & $100^{\mathrm{b}}$ & $100^{\mathrm{b}}$ & $88,45^{\mathrm{abc}}$ \\
\hline \multirow{3}{*}{30} & 1 & $100^{\mathrm{b}}$ & $94,30^{\mathrm{a}}$ & $87,45^{\mathrm{ab}}$ \\
& 2 & $100^{\mathrm{b}}$ & $95,80^{\mathrm{ab}}$ & $87,70^{\mathrm{abc}}$ \\
& 3 & $100^{\mathrm{b}}$ & $100^{\mathrm{b}}$ & $89,10^{\mathrm{bc}}$ \\
\hline \multirow{2}{*}{45} & 1 & $98,65^{\mathrm{a}}$ & $100^{\mathrm{b}}$ & $88,65^{\mathrm{abc}}$ \\
& 2 & $100^{\mathrm{b}}$ & $100^{\mathrm{b}}$ & $89,30^{\mathrm{c}}$ \\
& 3 & $100^{\mathrm{b}}$ & $100^{\mathrm{b}}$ & $90,95^{\mathrm{d}}$ \\
\hline
\end{tabular}

Keterangan : Angka rerata yang diikuti huruf yang sama pada kolom yang sama tidak berbeda nyata pada uji Duncan 5\%

Berdasarkan Tabel 2, tingkat kecerahan tepung ubijalar tertinggi diperoleh pada perlakuan lama perendaman 45 menit dan konsentrasi Natrium Metabisulfit $3 \mathrm{~g} / \mathrm{L}$ yakni dengan nilai kecerahan 100, sedangkan tingkat kecerahan terendah diperoleh pada perlakuan lama perendaman 30 menit dan konsentrasi natrium metabisulfit 1 gram yakni dengan nilai 94,30. Hal ini menunjukkan bahwa peningkatan lama waktu perendaman hingga 45 menit semakin mampu mempertahankan tingkat kecerahan tepung ubijalar.

Setelah ubijalar ungu dikupas, maka enzim glukosidase secara langsung menghidrolisis ikatan antara gugus aglikon dan gugus glikon pada ubijalar, sehingga cincin aromatik terbuka dan terdegradasi menjadi senyawa kalkon yang menyebabkan penurunan kadar zat antioksidannya (Harijono dkk 2000). Penelitian Nida dkk (2013) melaporkan bahwa setelah pengupasan dan dibiarkan selama 1 jam dalam suhu kamar, terjadi penurunan senyawa antioksidan pada umbi ubijalar.

Natrium Metabisulfit dapat menghambat proses pencokelatan dalam bahan, sebab Natrium Metabisulfit dapat mencegah terjadinya reaksi maillard yang dialami umbi ubijalar, yakni reaksi yang terjadi antara enzim glukosidase dan asam amino yang menyebabkan gula terdegradasi menjadi furfural. Furfural ini berkondensasi dengan senyawa fenol sehingga senyawa fenol dalam bahan terdegradasi. Dalam penelitian ini, tingkat kecerahan tepung ubijalar dapat dipertahankan dengan peningkatan lama perendaman untuk menghambat reaksi oksidasi bahan agar tidak mudah terdegradasi. Menurut Syarief dan Irawati (1988), natrium metabosulfit berperan sebagai bahan pengawet yang akan bereaksi terhadap gugus karbonil dan mengikat melanoidin sehingga mampu mencegah reaksi pencokelatan (browning).

Hasil analisis ragam tepung jagung menunjukkan bahwa faktor lama perendaman, faktor konsentrasi natrium metabisulfit serta interaksi antara perlakuan lama perendaman dan konsentrasi natrium metabisulfit memberikan pengaruh nyata $(\alpha=0,05)$ terhadap tingkat kecerahan tepung jagung. Artinya, peningkatan lama waktu perendaman dan penambahan natrium metabisulfit dapat meningkatkan kecerahan tepung jagung. Tingkat kecerahan tepung ubijalar dengan perlakuan kombinasi lama perendaman dan konsentrasi natrium metabisulfit berada pada kisaran nilai 87,30 - 90,95 (Tabel 2).

\section{KESIMPULAN}

Perlakuan terbaik hasil penelitian dipilih dengan membandingkan parameter yang diteliti pada masing-masing kombinasi perlakuan (Tabel 3). Kombinasi perlakuan yang memiliki nilai tertinggi untuk tiap parameter adalah perlakuan terbaik.

Berdasarkan Tabel 3, penelitian ini menghasilkan kesimpulan bahwa perlakuan $\mathrm{A} 3 \mathrm{~N} 3$ yakni kombinasi lama perendaman 45 menit dan konsentrasi Natrium Metabisulfit $3 \mathrm{~g} / \mathrm{l}$ merupakan perlakuan terbaik dilihat dari hasil uji tingkat kecerahan dan kadar vitamin $\mathrm{C}$ pada tepung ubi jalar, jika dibandingkan berdasarkan bahan yang diuji yakni tepung singkong dan tepung jagung. Sehingga 
tepung ubijalar dengan perlakuan tersebut memiliki karakteristik dan kualitas yang terbaik sebagai komoditi sumber pangan lokal substitusi tepung terigu.

\begin{tabular}{lcc}
$\begin{array}{c}\text { Tabel 3. Kadar Vitamin C dan Tingkat Kecerahan Tepung Ubi } \\
\text { Jalar, Tepung Singkong dan Tepung Jagung terhadap Variasi } \\
\text { Lama Perendaman dalam Berbagai Konsentrasi Natrium } \\
\text { Metabisulfit }\end{array}$ \\
\hline \multicolumn{1}{c}{ Parameter } & $\begin{array}{c}\text { Hasil } \\
\text { Penelitian }\end{array}$ & $\begin{array}{c}\text { Perlaku } \\
\text { an }\end{array}$ \\
\hline Kecerahan Tepung Singkong & 100 & A1N3 \\
Kecerahan Tepung Ubijalar & 100 & A3N3 \\
Kecerahan Tepung Jagung & 90,95 & A2N3 \\
K.Vit C Tepung Singkong & $3,73 \mathrm{mg}$ & A2N3 \\
K.Vit C Tepung Ubijalar & $7,90 \mathrm{mg}$ & A3N3 \\
K.Vit C Tepung Jagung & $5,93 \mathrm{mg}$ & A1N3 \\
\hline
\end{tabular}

\section{DAFTAR PUSTAKA}

Andoko, A., \& Parjimo. (2007). Budi Daya Singkong: umbi jalar, Jakarta; Agromedia Pustaka.

Asgar, A., \& Musaddad, D. (2008). Pengaruh Suhu dan Lama Blansing Sebelum Pengerngan terhdap Mutu Lobak Kering. J. Hort, 18(1), 87-94. Balai Penelitian Tanaman Sayuran. Bandung

Departemen Kesehatan RI. (1996). Daftar Komposisi Bahan Makanan. Bhratara, Jakarta.

Harijono, N., Basuki, S.S., Antarlina, \& Heriyanto. (2000). Rekayasa Teknologi Pengolahan Dalam Rangka Pengembangan Agroindustri Berbasis Ubi jalar. Laporan Kerjasama Unibraw dengan ARMP-II dan Badan Litbang Pertanian. 56p.

Hidayat, B., Ahza, A.B., \& Sugiyono. (2007). Karakterisasi Tepung Ubi Jalar (Ipomoea batatas L.) Varietas Shiroyutaka Serta Kajian Potensi Penggunaannya Sebagai Sumber Pangan Karbohidrat Alternatif. Jurnal Teknologi dan Industri Pangan, 18(1), 32-39.

Murtiningrum dkk. (2012). Karakteristik Umbi dan Pati Lima Kultivar Ubi Kayu (Manihot esculenta). Papua Barat: Teknologi Pertanian UNIPA, 3(1)

Nida, E.H., Melly, N., \& Syarifah, R. (2013). Kandungan Antosianin dan Aktivitas Antioksidan Ubi jalar Ungu Segar dan produk Olahannya. Agritech, 33(3), 1-7.

Prabawati, S., Richana, N., \& Suismono. (2011). Inovasi Pengolahan Singkong Meningkatkan Pendapatan dan Diversifikasi Pangan. Tabloid Sinar Tani 4(10), 3404.

Rukmana, R. (1997). Ubi Jalar: Budidaya dan Pascapanen. Yogyakarta: Penerbit Kanisius
Syarief, \& Irawati. (1988). Pengetahuan Bahan untuk Industri Pertanian. Jakarta: Mediyatama Sarana Perkasa. 